\title{
UPAYA PENGEMBANGAN SOFT SKILLS MELALUI IMPLEMENTASI MODEL PEMBELAJARAN KOOPERATIF UNTUK PENINGKATAN AKTIVITAS DAN HASIL BELAJAR MAHASISWA PADA PEMBELAJARAN KIMIA DASAR
}

\author{
I Ketut Sudiana \\ Jurusan Pendidikan Kimia, Fakultas MIPA, Universitas Pendidikan Ganesha, \\ Singaraja, Indonesia
}

\begin{abstract}
Abstrak
Penelitian ini adalah penelitian tindakan kelas (PTK) yang bertujuan (1) meningkatkan aktivitas belajar mahasiswa pada pembelajaran Kimia Dasar, (2) meningkatkan hasil belajar mahasiswa pada pembelajaran Kimia Dasar, dan (3) mendeskripsikan persepsi mahasiswa terhadap upaya pengembangan soft skills melalui implementasi model pembelajaran kooperatif untuk peningkatan aktivitas dan hasil belajar mahasiswa pada pembelajaran Kimia Dasar. Subjek penelitian ini adalah mahasiswa Semester I (Kelas B) Jurusan Pendidikan Biologi FMIPA Universitas Pendidikan Ganesha Tahun akademik 2011/2012, yang mengikuti perkuliahan Kimia Dasar sebanyak 22 mahasiswa. Objek penelitian ini adalah upaya atau tindakan peningkatan soft skills mahasiswa yang diterapkan, kepemilikan atribut soft skills mahasiswa, persiapan belajar mahasiswa (tugas reviu), aktivitas mahasiswa dalam pembelajaran, hasil belajar mahasiswa, dan persepsi mahasiswa terhadap model pembelajaran yang diterapkan. Hasil penelitian menunjukkan bahwa tindakan yang diterapkan dalam penelitian ini dapat (1) meningkatkan soft skills mahasiswa, (2) meningkatkan aktivitas belajar mahasiswa, (3) meningkatkan hasil belajar mahasiswa, dan (4) mahasiswa memberikan respon positif terhadap upaya pengembangan soft skills yang dimplementasikan melalui model pembelajaran kooperatif.
\end{abstract}

Kata kunci: Pengembangan soft skills, model pembelajaran kooperatif, Kimia Dasar

\begin{abstract}
This classroom action research aimed at (1) improving students' activities on Basic Chemistry subject, (2) improving student's achievement, (3) gaining students' perception towards the efforts of soft skills development by implementing cooperative learning model to improve students' activities and achievement on Basic Chemistry subject. The subjects of this research were all first semester students of class B (including 22 students) of Biology Education Department, Faculty of Mathematics and Science, Ganesha University of Education in the academic year 2011/2012. The objects of the research were the efforts of improving the students' soft skills, soft skill atribut ownership of the students, students learning preparation (review), students' activities during learning process, students' achievement, and students' perception towards the implemented model. The results of the study showed that the implementation of cooperative learning model were (1) improving the students' soft skills, (2) improving student's activities, (3) improving student's achievement, (4) student's positive response towards the efforts of soft skills development implemented through cooperative learning model.
\end{abstract}

Keywords: Soft skills development, cooperative learning model, Basic Chemistry 


\section{PENDAHULUAN}

Dalam konteks kehidupan bermasyarakat, berbangsa dan bernegara terjadi gejala anomali (sesuatu yang ganjil dan seharusnya tidak terjadi), seperti: (1) korupsi terjadi pada kaum terdidik, (2) pelanggaran hukum justeru dilakukan oleh aparat penegak hukum, (3) dunia olah raga yang seharusnya menjunjung tinggi nilainilai sportivitas sering dikotori praktik tidak terpuji mengatur score pertandingan dan dibarengi praktik suap, (4) anggota DPR dengan sebutan dewan terhormat sering menunjukkan perilaku tidak terhormat, (5) para pendidik berprilaku tidak terdidik dengan ikut terlibat praktek membocorkan soal atau kunci jawaban ujian nasional (UN), dan (6) pejabat yang menyalahgunakan jabatannya. Kejadian tersebut merupakan fenomena bukti ketertinggalan akibat dari kegagalan atau ketidaksempurnaan pendidikan, terutama pendidikan karakter.

Pendidikan karakter di sekolah merupakan kebutuhan vital agar generasi penerus dapat dibekali dengan kemampuankemampuan dasar yang tidak saja mampu menjadikannya life-long learners sebagai salah satu karakter penting untuk hidup di era informasi yang bersifat global, tetapi juga mampu berfungsi dengan peran serta yang positif. Untuk itu harus dilakukan upaya-upaya instrumental untuk meningkatkan keefektifan proses pembelajarannya disertai pengembangan kultur yang positif (Darmiyati Zuchdi, dkk. 2010: 1)

Pendidikan sebagai usaha sadar manusia untuk memanusiakan manusia ke arah yang lebih baik kurang berhasil atau dengan kata lain gagal. Salah satu penyebabnya adalah akibat dari pergeseran makna pendidikan ke arah pengajaran. Sekarang ini proses pembelajaran "kering" dengan transaksi pendidikan nilai (transformation of value), dan lebih menitikberatkan pada aspek pengetahuan (transformation of knowledge), atau dengan kata lain pendidikan kita lebih menekankan aspek teknis atau keterampilan keras (hard skills), kurang menekankan keterampilan lunak (soft skills). Sejalan dengan hal ini, Baedowi, Direktur Jenderal PMPTK Depdiknas, sebagaimana dikutip Triatmanto (2010), menyatakan bahwa saat ini ada kecenderungan masyarakat maupun sekolah sekadar memacu siswa untuk memiliki kemampuan akademik tinggi tanpa diimbangi pembentukan karakter yang kuat dan cerdas. Upaya sekolah maupun orang tua agar murid atau anaknya mencapai nilai akademis tinggi sangat kuat, tapi mengabaikan hal-hal yang non akademis.

Walaupun kondisi sebagaimana dipaparkan di atas sudah menjadi pengetahuan atau "rahasia umum", dan bahkan sudah menjadi keprihatinan banyak pihak, akan tetapi belum banyak tindakan nyata yang diarahkan untuk memperbaiki kondisi tersebut. Kegiatan pendidikan di sekolah dan kegiatan pembelajaran oleh guru di kelas, belum secara terprogram dan terstruktur memasukkan aspek soft skills dalam kegiatan belajar mengajar. Sadar atau tidak, sesungguhnya sedikit saja metode pembelajaran diperbaiki, bisa saja menghasilkan hasil pembelajaran yang dahsyat (Elfindri, dkk. 2010: 9). Dalam penelitian ini pembelajaran akan diperbaiki dengan metode pembelajaran yang memberikan peluang pengembangan soft skills anak didik.

Soft skills didefinisikan sebagai "personal and interpersonal behaviours that develop and maximize human performance (e.g. coaching, team building, initiative, decision making, etc). soft skills does not include Jurnal Pendidikan Indonesia | 92 
technical skills such as financial, computing and assembly skills " (Berthal dalam Illah Sailah, 2007).

Dari penelusuran atau kajian formal yang pernah dilakukan, ditemukan yang membawa atau mempertahankan orang di dalam sebuah kesuksesan $80 \%$ ditentukan oleh soft skills yang dimilikinya dan $20 \%$ oleh hard skillsnya (Illah Sailah, 2007). Sejalan dengan pernyataan tersebut maka kesuksesan mahasiswa dalam mengikuti perkuliahan juga ditentukan oleh faktor soft skills selain hard skills (potensi akademiknya). Untuk meningkatkan soft skills mahasiswa salah satunya dapat ditempuh dengan cara mensinergikan antara soft skills dan hard skills dalam perkuliahan.

Pengembangan soft skills dapat dilakukan melalui proses pembelajaran (intrakurikuler) dan kegiatan kemahasiswaan (ekstrakurikuler). Pengembangan soft skills melalui kegiatan belajar atau tatap muka di dalam kelas memerlukan kreativitas dosen pengampu mata kuliah dengan tetap pada pencapaian kompetensi mata kuliah tersebut. Pengembangan soft skills melalui kurikulum dapat ditempuh dengan dua cara. Pertama, melalui kegiatan pembelajaran yang secara ekplisit diintegrasikan dalam mata kuliah yang dituangkan dalam Silabus, SAP (Satuan Acara Perkuliahan) atau RPP (Rencana Pelaksanaan Pembelajaran). Kedua, dapat dilakukan melalui proses hidden curriculum, yaitu suatu strategi pengembangan soft skills yang disampaikan oleh dosen kepada mahasiswa secara terintegrasi pada saat perkuliahan berlangsung. Biasanya, cara kedua ini dilakukan dosen melalui panutan (contoh atau teladan), dan juga melalui pesanpesan selingan pada saat pelaksanaan perkuliahan menggunakan kata-kata mutiara, lagu-lagu, pribahasa, cerita, film (video clip), yang memotivasi dan inspiratif, dan tidak kalah penting adalah peran pimpinan (dosen) sebagai role model (Sriartha dan Sudiana, 2009: 6).

Dalam pembelajaran kooperatif siswa belajar dalam kelompok-kelompok kecil yang memiliki tingkat kemampuan berbeda. Dalam menyelesaikan tugas kelompok, setiap anggota saling bekerja sama dan membantu untuk memahami suatu bahan pembelajaran. Belajar belum selesai jika salah satu teman dalam kelompok belum menguasai bahan pembelajaran (Budi Jatmiko, 2004:7). Sebagaimana pembelajaran inovatif pada umumnya pembelajaran kooperatif bertujuan untuk meningkatkan prestasi belajar anak. Siswa akan belajar lebih efisien dalam proses pembelajaran kelompok ( $\mathrm{Te}-\mathrm{Yi}$ Chan, et al: 2008). Simon Attle dan Bob Baker (2007) juga menemukan bahwa melalui pembelajaran kooperatif siswa dapat memaksimalkan perkembangan profesional mereka. Selain itu, pembelajaran kooperatif masih memiliki keunggulan lain, yaitu banyak atribut soft skills dapat dilatihkan, seperti kerjasama (teamwork), keterampilan berkomunikasi, pengambilan keputusan, disiplin, manajemen waktu, kejujuran dan lain sebagainya.

Bersadarkan

pengalaman

memberikan kuliah Kimia Dasar di Jurusan Pendidikan Biologi FMIPA Undiksha, ditemukan beberapa kelemahan dalam pembelajaran, seperti (1) pelaksanakan perkuliahan belum dikelola dengan memperhatikan atau memberikan tempat pada aspek sosial pembelajaran, (2) umumnya mahasiswa cenderung belajar, bekerja, dan juga memecahkan permasalahan-permasalahan pembelajaran 
yang mereka hadapi sendiri-sendiri, (3) mahasiswa kurang terbiasa bekerja sama (sharing) dengan mahasiswa lainnya, (4) mahasiswa sering mengeluh jika diberikan tugas atau PR (Pekerjaan Rumah), (5) tidak disiplin atau suka menunda-nunda dalam mengerjakan tugas, yang dikalangan mahasiswa dikenal dengan istilah SKS (Sistem Kebut Semalam), dan (6) ketidakjujuran mengerjakan tugas, antara lain menyalin (copy paste) pekerjaan teman. Fakta ini memberikan indikasi bahwa soft skills mahasiswa masih rendah. Hal ini dapat menghambat pencapaian puncak prestasi akademiknya. Dosen harus memiliki pedagogi soft skills untuk tujuan meningkatkan soft skills mahasiswa.

Perlu dikondisikan pengelolaan pembelajaran yang memberikan peluang terjadi interaksi dan kerjasama antara mahasiswa satu dengan lainnya. Hampir semua siswa belajar lebih efisien pada saat mereka diperkenalkan untuk bekerja secara bersama-sama (cooperative) dengan siswa lainnya dalam satu kelompok atau tim. Menurut Vygotsky, interaksi sosial dengan teman lain memacu terbentuknya ide baru dan memperkaya perkembangan intelektual siswa (Ibrahim dan Nur., 2000:18). Ide kunci dari Vygotsky tentang aspek sosial belajar adalah konsepnya tentang zone of proximal development (zone perkembangan terdekat). Untuk mencapai zona perkembangan terdekat, perlu diciptakan lingkungan sosial belajar siswa agar tercipta masyarakat belajar (learning community). Model pembelajaran yang dapat menciptakan kondisi seperti itu adalah model pembelajaran kooperatif.

Berdasarkan uraian di atas agar terjadi peningkatan kualitas pembelajaran (aktivitas dan hasil belajar mahasiswa), dapat dilakukan melalui upaya peningkatan soft skills mahasiswa. Model pembelajaran yang memberi peluang paling tinggi terjadinya peningkatan soft skills adalah pembelajaran kooperatif. Oleh karena itu dalam penelitian ini dirumuskan judul "Upaya Pengembangan Soft skills Melalui Implementasi Model Pembelajaran Kooperatif untuk Peningkatan Aktivitas dan Hasil Belajar Mahasiswa pada Pembelajaran Kimia Dasar".

Adapun permasalahan dalam penelitian ini dapat dirumuskan sebagai berikut. (1) Apakah upaya pengembangan soft skills melalui implementasi model pembelajaran kooperatif dapat meningkatkan aktivitas belajar mahasiswa pada pembelajaran Kimia Dasar?, (2) Apakah upaya pengembangan soft skills melalui implementasi model pembelajaran kooperatif dapat meningkatkan hasil belajar mahasiswa pada pembelajaran Kimia Dasar?, dan (3) Bagaimanakah persepsi mahasiswa terhadap upaya pengembangan soft skills melalui implementasi model pembelajaran kooperatif pada pembelajaran Kimia Dasar?

Tujuan umum penelitian ini adalah (1) meningkatkan aktivitas belajar mahasiswa pada pembelajaran Kimia Dasar, (2) meningkatkan hasil belajar mahasiswa pada pembelajaran Kimia Dasar, dan (3) mengetahui persepsi mahasiswa terhadap upaya pengembangan soft skills melalui implementasi model pembelajaran kooperatif untuk peningkatan aktivitas dan hasil belajar mahasiswa pada pembelajaran Kimia Dasar. Penerapan model pembelajaran ini diharapkan dapat bermuara pada terjadinya peningkatan soft skills mahasiswa yang memberi dampak meningkatkan aktivitas dan hasil belajar mahasiswa. 
Model pembelajaran dapat membantu guru untuk mencapai tujuan pembelajaran yang berdimensikan sosial dan hubungan antar manusia. Belajar secara kooperatif dikembangkan berdasarkan teori belajar kognitifkonstruktivis dan teori belajar sosial. Gagasan dalam kerja kooperatif memberikan penekanan kegunaanya pada pencapaian tujuan dan kesuksesan kelompok, dimana keberhasilan belajar dicapai hanya jika seluruh anggota kelompok mencapai tujuan pembelajarannya (Slavin, Robert E., 1995:5). Keberhasilan dalam belajar bukan semata-mata harus diperoleh dari guru, melainkan bisa juga dari pihak lain yang terlibat dalam pembelajaran itu, yaitu teman sebaya (Hilda Karli dan Margaretha Sriyuliariatiningsih, 2002). Tujuan dibentuk kelompok kecil dalam implementasi model pembelajaran kooferatif adalah untuk memberi kesempatan yang sama kepada semua mahasiswa yang terlibat secara aktif dalam kegiatan belajar (Suryanti, 1998). Menurut Johnson dan Johnson, ada lima unsur pokok yang harus diperhatikan dalam pembelajaran kooperatif, yaitu (1) saling ketergantungan yang positif, (2) peningkatan interaksi antarsiswa, (3) peningkatan tanggung jawab individu, (4) pembentukan keterampilan dan kemampuan sosial, (5) proses kelompok, yaitu terjadi hubungan kerjasama yang efektif. (Ballanca, James, 1995).

\section{METODE PENELITIAN}

Subjek dari penelitian ini adalah mahasiswa Semester I (Kelas B) Jurusan Pendidikan Biologi FMIPA Universitas Pendidikan Ganesha Tahun akademik 2011/2012, yang mengikuti perkuliahan Kimia Dasar sebanyak 22 mahasiswa. Objek penelitian ini adalah upaya atau tindakan peningkatan soft skills mahasiswa yang diterapkan, kepemilikan atribut soft skills mahasiswa, persiapan belajar mahasiswa (tugas reviu), aktivitas mahasiswa dalam pembelajaran, hasil belajar mahasiswa, dan persepsi mahasiswa terhadap model pembelajaran yang diterapkan. Penelitian ini mengambil desain penelitian tindakan kelas (PTK) menggunakan prosedur pembelajaran kooperatif STAD (Student Teams Achievement Division).

\section{Tindakan Siklus I}

Tindakan pada siklus I terdiri dari: (1) Pada awal perkuliahan, yaitu pada pertemuan untuk pertama kalinya, kepada mahasiswa diberikan SAP (Satuan Acara Perkuliahan) Kimia Dasar yang berisikan tentang: kompetensi standar, kompetensi dasar, indikator, materi pokok, dan sub materi pokok serta atribut soft skills yang ingin atau dapat dikembangkan, (2) Pembentukan kelompok, setiap kelompok terdiri dari 3-5 orang mahasiswa, bersifat heterogen berdasarkan kemampuan dan jenis kelamin, (3) Satu minggu sebelum perkuliahan pokok bahasan tertentu, kepada mahasiswa diberikan tugas membuat reviu pokok bahasan dan/atau tugas lainnya, (4) Setiap kali perkuliahan diberikan tindakan berupa pengembangan soft skills mahasiswa yang dilakukan oleh dosen. Alternatif strategi pengembangan soft skills yang dapat dilakukan seperti lagu-lagu, testimoni, cerita inspiratif, gambar, video clip, dengan durasi antara 5-7 menit, (5) Perkuliahan diselenggarakan dengan presentasi hasil reviu pokok bahasan dan/atau tugas oleh kelompok mahasiswa dilanjutkan dengan diskusi, (6) Setelah presentasi dan diskusi akan lahir permasalahan atau pertanyaan-pertanyaan 
yang berasal dari mahasiswa ataupun dari dosen. Permasalahan dan pertanyaan dikoleksi, untuk kemudian pada akhir pelaksanaan presentasi dan diskusi kepada mahasiswa diminta untuk menjawabnya (tugas individu). Karena pertimbangan waktu yang tersedia terbatas, maka untuk maksud ini dari sejumlah permasalahan atau pertanyaan yang muncul dipilih antara 3 sampai dengan 5 permasalahan/pertanyaan yang substansinya paling relevan dengan kompetensi dasar pokok bahasan yang sedang dikaji. Hasil pekerjaan mahasiswa dikumpulkan saat itu untuk kemudian dinilai. Nilai yang diperoleh mahasiswa menunjukkan tingkat perkembangan aktual mahasiswa, (7) Tugas (permasalahan dan pertanyaan) yang sama dengan point 5 di atas, kembali ditugaskan kepada mahasiswa untuk dikerjakan secara berkelompok di rumah sebagai PR (pekerjaan rumah), (8) Pertemuan berikutnya (seminggu kemudian) hasil pekerjaan mahasiswa secara berkelompok dikumpulkan untuk dinilai sebagai nilai kelompok. Nilai ini menunjukkan tingkat perkembangan terdekat bagi mahasiswa setelah dibantu teman sejawat. Berbagai hal yang masih belum dapat dikerjakan dalam kerja kelompok dapat ditanyakan kepada dosen untuk didiskusikan, (9) Pada setiap akhir siklus pembelajaran terdiri atas beberapa pokok bahasan (kompetensi dasar) dilaksanakan tes hasil belajar. Nilai tes yang dicapai mahasiswa akan menunjukkan tingkat perkembangan terdekat mahasiswa setelah pembelajaran dibantu teman sejawat dan dosen.

\section{Refleksi Tindakan I}

Berdasarkan hasil observasi dan evaluasi seperti disajikan di atas maka dapat dibuat refleksi tindakan I sebagai berikut. (1)
Aktivitas belajar mahasiswa siklus I: partisipasi dalam presentasi-diskusi kategori cukup; spontanitas mahasiswa dalam presentasi-diskusi kategori baik; dan antusiasme mahasiswa dalam presentasidiskusi adalah cukup. (2) Nilai tugas membuat reviu pokok bahasan baik. (3) Nilai perkembangan aktual mahasiswa kurang. (4) Nilai perkembangan terdekat baik. (5) Nilai tes akhir cukup. (6) Mahasiswa masih mengalami kesulitan dalam menjawab soalsoal yang menuntut penalaran dan argumentasi. (7) Penilaian secara autentik masih rendah. (8) Presentasi dan diskusi berjalan kurang efektif. Meminta mahasiswa agar bersedia secara sukarela mempresentasikan tugasnya agak sulit terlaksana atau tidak lancar. Pada awalnya tidak ada yang secara spontan mau mempresentasikan tugasnya. (9) Mahasiswa kurang terampil dalam mengemukakan pertanyaan/pendapat secara lisan. (10) Pada saat presentasi, partisipasi anggota kelompok dalam presentasi dan diskusi kurang baik. Ada mahasiswa yang dominan dan ada mahasiswa yang perannya sangat minimal. (11) Pada Siklus I mahasiswa dalam mempresentasikan tugasnya lebih banyak membaca apa yang sudah mereka tulis atau ditayangkan dilayar dengan media Powerpoint. Belum disertai uraian, argumentasi, penjelasan tambahan, atau penalaran. (12) Media Powerpoint yang dibuat mahasiswa masih belum baik, kurang menarik (dilihat dari desain dan layout), kurang sistematis, terlalu banyak animasi yang tidak penting, dan kurang dilengkapi gambar atau video yang dapat memperkuat pesan/informasi yang hendak disampaikan. (13) Mahasiswa masih terkesan enggan, merasa takut, kurang percaya diri dalam presentasi dan diskusi. Mahasiswa kurang lancar dan masih grogi Jurnal Pendidikan Indonesia | 96 
dalam berkomunikasi. (14) Kelompok mahasiswa kurang kerjasama dalam presentasi maupun dalam diskusi. (15) Permasalahan yang diajukan mahasiswa dalam diskusi kurang fokus atau sering keluar dari tuntutan kompetensi dasar sebagaimana tertuang dalam SAP. (16) Mahasiswa yang tidak presentasi kurang ada kesiapan dalam diskusi, sehingga kurang aktif dalam diskusi. (17) Mahasiswa dalam menyampaikan gagasan, bertanya, menjawab pertanyaan sering tidak dapat disampaikan secara jelas dan operasional. (18) Terjadinya peningkatan skor rerata antara perkembangan aktual dan perkembangan terdekat. (19) Pada siklus I, dari 12 atribut soft skills yang menjadi fokus pengembangan, terdapat 3 atribut sudah kategori baik atau sangat baik, yaitu kerjasama, menghargai orang lain, dan kejujuran. Atribut soft skills yang dinilai masih perlu dikembangkan, yaitu masih berada pada kategori cukup atau kurang, yaitu keterampilan berkomunikasi, manajemen waktu, disiplin, motif berprestasi, berpikir kritis, berargumentasi logis, antusiasme, bertanggung jawabdan kepercayaan diri. (20) Pemberian soft skills di awal perkuliahan terkadang tidak efektif, karena pesan soft skills yang diberikan terkadang tidak tepat momen atau konteksnya.

\section{Tindakan Siklus II}

Berdasarkan hasil refleksi tindakan pada siklus I, maka pada siklus II modifikasi tindakan dilakukan seperti di bawah ini. (1) Kelemahan presentasi yang kurang efektif pada siklus I karena materi pokok bahasan yang cukup luas disajikan hanya oleh satu kelompok, maka pada siklus II materi presentasi untuk satu pokok bahasan dibagi menjadi 2 bagian, dan disajikan oleh 2 kelompok secara bergiliran. Dengan demikian lebih banyak mahasiswa yang memperoleh kesempatan presentasi. (2) Powerpoint yang disiapkan mahasiswa untuk presentasi disarankan untuk melengkapi dengan gambar atau video, agar infomasi atau penjelasan menjadi lebih mudah dipahami. (3) Setiap mahasiswa diminta atau ditugaskan menyiapkan pertanyaan atau permasalahan yang akan diajukan atau didiskusikan pada saat presentasi dan diskusi. Permasalahan atau pertanyaan ini disiapkan secara tertulis untuk mengatasi kendala mengkomunikasikan gagasan oleh mahasiswa langsung secara lisan. (4) Pengembangan soft skills pada siklus I lebih banyak diberikan pada awal perkuliahan. Cara ini dinilai kurang efektif dilihat dari momennya. Pada siklus II upaya pengembangan soft skills diberikan bisa diawal, diakhir, atau di tengah-tengah jika dipandang ada momentum yang tepat untuk memberikan soft skills. Pesan atau atribut soft skills yang diberikan disesuaikan dengan situasi dan kondisinya. Cara penyampaian pesan soft skills antara lain dengan cerita, gambar, dan atau video dengan kisaran waktu \pm 5 smapai dengan 7 menit. (5) Agar diskusi dapat dikelola lebih sistematis dan terorganisir, maka pertanyaan-pertanyaan yang diajukan mahasiswa tidak langsung ditanggapi, melainkan terlebih dahulu dikoleksi (diinventarisir) oleh mahasiswa dan juga oleh dosen pengajar. Selanjutnya dosen pengajar membantu menyusun dan mengurut pertanyaan-pertanyaan yang diajukan oleh mahasiswa agar diskusi dan pembahasan menjadi lebih sistematis dan terorganisir. (6) Agar terjadi tanggung jawab bersama oleh anggota kelompok dalam presentasi, maka tugas presentasi Jurnal Pendidikan Indonesia | 97 
disarankan untuk berbagi dan begitu pula halnya dalam menanggapi pertanyaanpertanyaan oleh mahasiswa lainnya. (7) Kepada mahasiswa pada saat presentasi diminta tidak hanya membacakan tugas reviunya, tetapi juga dituntut agar mampu memberikan uraian atau penjelasan tambahan.

\section{Refleksi Siklus II}

Hasil observasi dan evaluasi setelah dilaksanakan tindakan II dapat dibuat refleksi siklus II sebagai berikut. (1) Rerata nilai partisipasi presentasi-diskusi pada siklus II adalah 3,1 dengan kategori baik. Terdapat peningkatan aktivitas presentasidiskusi yang signifikan dari cukup pada siklus I menjadi baik pada siklus II. Rerata nilai spontanitas mahasiswa dalam presentasi-diskusi 3,0 dengan kategori baik. Terdapat peningkatan spontanitas dalam presentasi-diskusi 2,5 (baik) pada siklus I menjadi 3,0 (baik) pada siklus II. Aktivitas belajar mahasiswa dilihat dari antusiasme dalam presentasi-diskusi adalah baik. Terjadi kenaikan rerata nilai antusiasme cukup pada siklus I menjadi baik pada siklus II. (2) Nilai tugas membuat reviu pokok bahasan pada Siklus II adalah sangat baik. Terdapat kenaikan rerata skor membuat tugas reviu pokok bahasan dibandingkan pada siklus I, yaitu dari baik menjadi sangat baik. (3) Nilai perkembangan aktual mahasiswa pada siklus II adalah kurang. Nilai perkembangan aktual lebih baik daripada siklus I, yaitu dari 37,2 (sangat kurang) menjadi 46,7 (kurang). (4) Nilai perkembangan terdekat pada siklus II kategori baik. Terjadi sedikit peningkatan dibandingkan pada siklus I 79,2 (baik) menjadi 80,8 (baik) pada siklus II. (5) Nilai tes akhir pada siklus II adalah 82,1 dengan kategori baik. Terjadi peningkatan nilai tes akhir yang signifikan dibandingkan pada siklus I. Pada siklus I rerata nilai tes akhir 66,1 (cukup) menjadi rerata 82,1 (baik) pada siklus II. (6) Kepemilikan atribut soft skills oleh mahasiswa juga mengalami peningkatan. Rerata skor kepemilikan atribut soft skills pada siklus I cukup meningkat menjadi baik pada siklus II. (7) Upaya perbaikan tindakan pada siklus II, seperti membagi materi presentasi menjadi dua bagian memberikan peluang presentasi kepada lebih banyak mahasiswa ternyata mampu menjadikan presentasi lebih lancar dan aktivitas belajar juga meningkat. Demikian pula halnya dengan pemberian materi soft skills yang disesuaikan dengan momen (relevan dengan situasi dan kondisi) lebih mengena atau lebih bermakna bagi mahasiswa. Keseluruhan perbaikan tindakan pada siklus II terbukti telah mampu meningkatkan hasil belajar mahasiswa.

\section{HASIL PENELITIAN}

Aktivitas belajar mahasiswa diukur dengan menggunakan parameter 1) partisipasi dalam presentasi-diskusi, 2) spontanitas dalam presentasi-diskusi, dan 3) antusiasme dalam mengikuti pembelajaran. Dari data penelitian diperoleh bahwa ketiga parameter tersebut menunjukan adanya peningkatan dari siklus I ke siklus II. Untuk parameter partisipasi dalam presentasidiskusi, naik dari 2,2 (cukup) menjadi 3,1 (baik). Untuk parameter spontanitas dalam presentasi-diskusi, naik dari 2,5 (baik) menjadi 3,0 (baik). Sedangkan untuk parameter antusiasme dalam mengikuti pembelajaran, terjadi kenaikan dari 2,0 (cukup), dan 3,0 (baik).

Aktivitas belajar mahasiswa juga diukur dari performance (kinerja) mahasiswa selama pembelajaran berlangsung. Pengukuran secara autentik (autentik Jurnal Pendidikan Indonesia | 98 
asesmen) menunjukkan bahwa kinerja mahasiswa mengalami peningkatan dari siklus I dan II. Kinerja mahasiswa tersebut dilihat dari jumlah mahasiswa berpartisipasi, frekuensi partisipasi, dan kualitas (skor) partisipasi mahasiswa. Untuk parameter kinerja mahasiswa dalam pembelajaran, terjadi kenaikan dalam hal jumlah mahasiswa berpartisipasi secara aktif dari 15 orang menjadi 21 orang, frekuensi partisipasi dari 20 menjadi 32, dan skor kinerja dari 37 menjadi 67.

Hasil belajar mahasiswa yang diukur dengan menggunakan parameter 1) nilai tugas membuat reviu pokok bahasan, 2) nilai perkembangan aktual, 3) nilai perkembangan terdekat, dan 4) hasil tes pada akhir siklus. Dari data penelitian diperoleh bahwa keempat parameter tersebut menunjukan adanya peningkatan dari siklus I ke siklus II. Untuk parameter tugas membuat reviu pokok bahasan, skor naik dari 84,2 (baik) menjadi 86,7 (sangat baik). Untuk nilai perkembangan aktual, skor naik dari 37,2 (sangat kurang) menjadi 46,7 (kurang). Untuk nilai perkembangan terdekat, skor naik dari 79,2 (baik) menjadi 80,8 (baik). Untuk nilai tes akhir siklus, skor naik dari 66,1 (cukup) menjadi 82,1 (baik).

Pada penelitian ini pengukuran atribut soft skills difokuskan pada 12 atribut soft skills yang dominan dapat dikembangkan. Pengukuran atribut soft skills dalam penelitian ini dinilai melalui pengisian angket masing-masing oleh diri sendiri (self evaluation), teman dalam kelompok, dan oleh dosen pengajar. Dari hasil pengukuran diperoleh terjadi peningkatan kepemilikan atribut soft skills dikalangan mahasiswa. Rerata skor soft skills mahasiswa pada siklus I adalah 3,4 (cukup) naik menjadi 3,7 (baik) pada siklus II.

\section{PEMBAHASAN}

Upaya pengembangan soft skills mahasiswa melalui model pembelajaran kooperatif pada pembelajaran Kimia Dasar dapat meningkatkan aktivitas belajar mahasiswa. Mahasiswa menjadi lebih aktif berpartisipasi dalam diskusi, lebih berani mengemukakan pendapat, dan lebih bersemangat (antusias). Upaya pengembangan soft skills berhasil meningkatkan kepemilikan atribut soft skills yang berpengaruh terhadap terjadinya peningkatan aktivitas belajar mahasiswa. Model pembelajaran kooperatif yang diterapkan juga mendorong aktivitas belajar mahasiswa menjadi lebih baik atau meningkat berkat diskusi, kerjasama, dan sharing yang terjadi dalam kelompok.

Dari hasil penelitian diperoleh bahwa kemampuan mahasiswa membuat tugas reviu pokok bahasan adalah baik. Data rerata nilai tugas membuat reviu yang baik adalah indikasi dari persiapan belajar mahasiswa yang baik, berkat peningkatan kepemilikan soft skills mahasiswa yang pada akhirnya berpengaruh terhadap semangat bekerja secara kooperatif.

Nilai perkembangan aktual mahasiswa dari siklus I dan II menunjukkan kecenderungan meningkat. Namun kenaikan hanya terjadi dari 37,2 (sangat kurang) pada siklus I menjadi 46,7 (kurang) pada siklus II. Dilihat dari parameter ini menunjukkan bahwa penguasaan mahasiswa terhadap bahan kuliah sebagai produk belajar individu ada pada kategori sangat kurang atau kurang. Aspek ini yang hendak ditingkatkan melalui model pembelajaran kooperatif.

Nilai perkembangan terdekat yang menunjukkan hasil belajar mahasiswa melalui proses pembelajaran kooperatif dari siklus I ke siklus II ada pada kategori baik. 
Hal ini menunjukkan hasil pencapain yang konsisten dengan kategori baik pada setiap siklusnya. Capaian hasil belajar tersebut dikontribusi oleh model pembelajaran kooperatif dan juga meningkatnya kepemilikan atribut soft skills mahasiswa. Mahasiswa mendapat manfaat dari belajar kooperatif. Artinya, antarmahasiswa telah terjadi sharing pengetahuan, dimana dalam belajar antarmahasiswa telah terjadi proses saling melengkapi, sehingga setiap mahasiswa mendapat manfaat berupa penguasaan materi kuliah menjadi lebih baik. Semangat untuk belajar secara kooperatif didukung oleh soft skills mahasiswa yang meningkat. Mahasiswa yang kemampuan akademisnya kurang mendapat bantuan dari mahasiswa yang memiliki penguasaan materi kuliah lebih baik. Mahasiswa yang penguasaan materi kuliah lebih baik juga mandapat hasil belajar dari kegiatannya membantu temannya yang kurang. Hal demikian itu sejalan dengan tujuan pembelajaran kooperatif, yaitu belajar belum selesai jika salah satu teman dalam kelompok belum menguasai bahan pembelajaran. (Budi Jatmiko, 2004: 7). Temuan dalam penelitian ini juga sejalan dengan konsep aspek sosial belajar menurut Vygotsky tentang zone of proximal development (zona perkembangan terdekat). Di mana pembelajaran terjadi melalui interaksi sosial dengan teman sejawat. Bantuan dari teman sejawat yang lebih mampu, siswa bergerak ke dalam zona perkembangan terdekat mereka di mana pembelajaran baru terjadi (Ibrahim dan Nur, 2000: 18-19). Malalui upaya pengembangan soft skills yang dipadukan dengan model pembelajaran kooperatif dapat menciptakan lingkungan sosial siswa (masyarakat) belajar (learning community), pembelajaran yang berpusat pada siswa (student centered), dan belajar lebih bermakna.

Penyelenggaraan tes di akhir siklus pada penelitian ini merupakan salah satu cara untuk mengukur hasil belajar mahasiswa. Rerata nilai hasil tes menunjukkan peningkatan secara signifikan dari siklus I ke siklus II. Nilai tes ini menunjukkan hasil belajar mahasiswa setelah tindakan upaya pengembangan soft skills mahasiswa melalui pembelajaran kooperatif. Nilai tes ini juga merupakan hasil belajar (perkembangan terdekat) mahasiswa setelah berinteraksi dengan teman sejawat dan dosen.

Tindakan piningkatan kepemilikan atribut soft skills di kalangan mahasiswa dapat dilakukan melalui cerita, penayangan gambar, dan pemutaran video yang inspiratif atau berisi muatan soft skills. Tindakan pemberian selingan materi soft skills lebih bermakna jika diberikan tepat pada momentumnya. Artinya, tepat waktu (bisa di awal kuliah, disisipkan saat perkuliahan, atau pada akhir perkuliahan), dan materi soft skills relevan dengan situasi dan kondisi saat itu. Respon mahasiswa terhadap upaya pengembangan soft skills melalui implementasi model pembelajaran kooperatif pada pembelajaran Kimia Dasar secara umum adalah positif dan berharap model pembelajaran ini dapat diterapkan pada mata kuliah lainnya.

\section{SIMPULAN DAN SARAN}

Berdasarkan hasil penelitian ini dapat dibuat simpulan sebagai berikut.

Upaya pengembangan soft skills melalui implementasi model pembelajaran kooperatif pada pembelajaran Kimia Dasar dapat (1) meningkatkan soft skills mahasiswa, (2) meningkatkan aktivitas belajar mahasiswa, (3) meningkatkan hasil 
belajar mahasiswa, dan (3) mahasiswa memberikan respon positif terhadap upaya pengembangan soft skills yang diimplementasikan melalui model pembelajaran kooperatif.

Implikasi dari penelitian ini adalah bahwa upaya pengembangan soft skills melalui implementasi model pembelajaran kooperatif layak untuk dicoba diterapkan pada mata kuliah lainnya. Agar penerapan model pembelajaran ini dapat memberikan hasil yang lebih optimal disarankan agar atribut soft skills yang menjadi pengembangan dapat diperluas dan perlu dikembangkan instrumen untuk pengukuran atribut soft skills.

\section{DAFTAR PUSTAKA}

Budi Djatmiko. 2004. Model-model Pembelajaran (DI, Kooperatif, dan $P B$ ). Makalah UNESA

Darmiyati Zuchdi, Zuhdan Kun Prasetya, dan Muhsinatun Siasah Masruri. 2010. Pengembangan Model Pendidikan Karakter Terintegrasi dalam Pembelajaran Bidang Studi di Sekolah Dasar. Jurnal Cakrawala Pendidikan, Mei 2010, Th. XXIX, Edisi Khusus Dies Natalis UNY. Halaman $1-12$

Elfindri, Jemmy Rumengan,. Muhammad Basri Wello, Poltak Tobing, Fitri Yanti, Zein, Elfa Eriyanti, dan Ristapawa Indra. 2010. Soft skills untuk Pendidik. Baduose Media.

Hilda Karli dan Margaretha Yuliariatiningsih. 2002. Implementasi Kurikulum Berbasis Kompetensi. Model-model Pembelajaran 2. Cetakan Pertama. Edisi Kesatu. Bandung: Bina Media Informasi.

Illah Sailah. 2007. "Pengembangan Soft skills di Perguruan Tinggi. Makalah disampaikan dalam rangka Sosialisasi Pengembangan Soft skills di Undiksha, tanggal 26 April 2007.
Ibrahim, Muslimin; Nur, Mohamad. 2004. Pengajaran Berdasarkan Masalah. Cetakan Kedua. Surabaya: UNESA University Press.

Slavin, Robert E. 1995. Cooperative Learning: Theory, Research, and Practice. Second Edition. USA: Allyn \& Bacon.

Simon Attle dan Bob Baker. 2007. Cooperative Learning in a Competitive Environment: Classroom Applications. International Journal of Teaching and Learning in Higher Education 2007, Volume 19, Number 1, $77-83$.

Sriartha, I Putu dan Sudiana, I Ketut. 2009. Buku Panduan Pengembangan Soft skills Mahasiswa Undiksha melalui Multilevel Role Model Berlandaskan Trikaya Parisudha. Universitas Pendidikan Ganesha. Singaraja

Suryanti. 1998. Pengembangan Model Pembelajaran Tipe Teams Game Turnamen (TGT) dalam Meningkatkan Hasil Belajar Fisika SMU. Tesis (tidak diterbitkan) IKIP Singaraja.

Te - Yi Chan, Rou - Mei Wang, Bin - Shyan Jong, Yen - The Hsia and Tsong Wuu Lin. 2008. Conceptual Graph Based Learning Material. Producing Strategy For Cooperative Learning. ASEE/IEEE Frontiers in Education Conference. $38^{\text {th }}$. $978-1-4244-$ 1970 - 8/08. October $22-25,2008$, Saratoga Springs, New York.

Triatmanto. 2010. Tantangan Implementasi Pendidikan Karakter di Sekolah. Jurnal Cakrawala Pendidikan, Mei 2010, Th. XXIX, Edisi Khusus Dies Natalis UNY. Halaman $187-203$ 